successes, but, rather, the opposite. It may very well be held that the council can always close down units after a period of 7 years but this seems not always to be as easy - or as quick - as the council likes to say. Further, it is rarely as painless or as comparatively free from pain as would be a decision not to renew a research grant to a research worker at a university. For this reason, it is somewhat disconcerting to see the council's announcement in its new report that the tendency of recent years to spend a greater proportion of the budget on short-term research grants is now to be modified in the interests of its own establishments. Ought things not to be moving in the other direction as, for that matter, they were doing in the late fifties?

One particularly disconcerting feature of the council's policy of direct labour is the way in which it may often leave middle-aged professionals high and dry without a job. One way and another, a great many people seem to be embarking on 5 year appointments with the council which run out at a time when it is usually too late for most people to begin an entirely new career. The zeal with which the council pursues what seems to be the support of individual excellence is admirable in many ways, of course, although many people thus dealt with may often find that the retirement of a director and not some personal failing is the reason for being out of work. Things seem to be especially difficult this year, with the universities cutting back on staff. Although the numbers concerned may be comparatively small, these problems of employment are at once serious in themselves and yet another prompter of the question whether the council would not be more effective and even more successful if it became more like a grantgiving agency and less like a cosy but largely autonomous research organization. Nobody suggests that the council should have less to spend-it needs moreor that its policy is entirely misguided. The problem which somebody should tackle is how to balance the undoubted advantages of research units against the equally identifiable disadvantages. That, perhaps, is where Dr J. A. B. Gray, the new secretary, should begin.

\section{Helter Smelter}

The British Government's plan for encouraging the development of aluminium smelting in Britain went ahead last week with the announcement of two more smelters at Holyhead and Invergordon. With a smelter already agreed for Lynemouth, in Northumberland, this will give the United Kingdom an additional 260,000 tons of aluminium smelting capacity and a saving of $£ 40$ million a year on the balance of payments. This is, of course, a distinctly good piece of news for the British economy, though optimists hope that the economy will not still be needing continual shots in the arm by 1970-71, when the smelters come into production. But that is about all that can be said in favour of the agreements, which break most of the rules good governments should follow both towards their own industries and towards their trading partners.
Because all three smelters will be in development areas, they will qualify for the usual investment grants, designed to encourage industry to move to areas of high unemployment. This is a perfectly normal part of the Government's policy of regional development, which is already so much a cornerstone of public policy that it may well outlive the problems it was designed to cure. But, in addition, the smelter companies have been lent substantial sums of money to enable them to buy special places in the electricity supply network. A consortium made up of Rio Tinto Zine, British Insulated Callender's Cables and Kaiser Aluminium, which is to build the smelter at Holyhead, is being lent $\mathfrak{} 33$ million, and British Aluminium, which

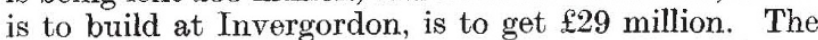
loans, which are to run over 30 years, carry an interest rate of 7 per cent.

The conpanies will use these loans to buy favourable terms from the generating boards. They will pay the boards a capital charge to cover the cost of earmarked electricity capacity in the most advanced power stations. As an accountant's rationalization of these calculations, it is said that the companies will in effect be paying a part of the capital cost of Dungeness $B$ power station, the first commercial advanced gas cooled reactor, which will be coming on stream at about the same time as the smelters. Neither smelter, of course, will be drawing power from Dungeness as such, but they will be paying for it as if they were. By virtue of their capital contributions, the companies will be charged only for the costs of the station which nominally supplies them; other users will continue to pay their share of the operating costs of the entire system. In practical terms, this means that electricity to the smelters will cost about $0 \cdot 6$ pence a unit, instead of perhaps 1.0 pence per unit for other large users. It is, of course, true that the smelters use impressive amounts of electricity. The one at Invergordon will be using 200 megawatts 24 hours a day, a consumption few other industries could approach. But even a gigantic appetite for power can hardly justify pricing policies which leave other large users, and the general public, at such a disadvantage.

What this means is that the large public investment in the development of cheaper sources of electricity will not now be used to bring down the price of electricity to the consumer. Instead, it will be used to bolster an industry which could not otherwise have been justified in Britain, and which ought by normal industrial logic to be sited near the sources of raw materials. The decision also seems to misconceive the real objectives of the regional development grants. The long-term aim should be to make the development regions selfsufficient. Although it may be necessary occasionally to give grants for setting up a new industry, such grants should be a once-and-for-all affair. Instead, the Government has devised an arrangement which will confer permanent advantages on the development areas. The industries which grow up around the smelters, far from being self-sufficient, will in their turn rely on the continued existence of the preferential treatment of the smelters. Finally, the Government has committed $£ 62$ million of public money for a return of (it is said) 7 per cent. The companies were clearly not under the same obligations as the nationalized industries, which have to show a return of at least 8 per cent on all public expenditure. 
It is certain that other industries which use electricity intensively will ask for the same treatment; the British Steel Corporation is an obvious candidate. Not the least of the difficulties is finding out what the terms of the contracts are: as $\mathrm{Mr}$ Anthony Crosland, President of the Board of Trade, said in the House of Commons, "I cannot tell him (the Hon. Member) the price. It is never revealed in contracts of this kind. I can assure him, however, that it is completely unsubsidized". The Government is already covering itself against claims from other users by saying that the demand must be "substantially new" or evidence must be produced that existing operations are becoming uneconomic. But this is no more than inventing principles to suit policies. Even the parlous state of the British balance of payments (which is at last showing signs of recovery) can hardly be held to justify such an arbitrary way of doing things.

\section{Data Processing Delayed}

THE Post Office plan to promote the use of computers by creating a National Data Processing Service (NDPS) seems to be barely off the ground, although the Bill giving the Post Office power to provide the data processing service became law last year. It is true that at the beginning of the current financial year the National Data Processing Service became a selfaccounting unit within the Post Office, but so far it has only one outside customer-the Customs and Excise Department, which is planning to start using the service in the early 1970 s to help with the documentation involved in the importation of goods through London Airport.

The philosophy behind the NDPS is that, by 1971 , the Post Office will have as many as twenty large computers. Several of the machines are for special applications, the control of the aerials at Goonhilly, for example, or will be part of the Giro banking system, but a number of the computers earmarked for commercial purposes within the Post Office are also suitable for use in the data processing system. The form the service will take has still not been publicized, but it seems there will be some flexibility to meet the needs of customers. Both on-line and off-line data processing will be provided.

Just now, the Post Office seems to be keeping quiet about the service, no doubt because at present its computers are heavily committed to Post Office work. Like all computer users, it is finding a shortage of experienced personnel; nevertheless it is reaching its target of 100 recruits a year to train as computer operators. Some of the delay in setting up the NDPS may also have its roots in the problem of starting the Giro system, itself ambitious enough.

\section{Contraception in South America}

IN his recent encyclical, the Popc has forbidden all forms of birth control with the exception of the so-called natural rhythm method. The prohibition covers all means of contraception, as well as abortion and sterilization. The burden of the Pope's sentiments is likely to be borne most heavily in Latin America, a predominantly Roman Catholic continent. How will the encyclical be received in Latin American countries?

Official policies towards birth control in Latin
America are a reaction to the peoples' manifest desire to limit their fertility. Given the attitude of the Church and state, this desire has to be expressed in the form of abortions, which have now reached epidemic proportions in some Latin American countries. In Chile, according to a statement by the Minister of Public Health, there is one illegal abortion for every two live births. In 1965,20 per cent of the beds in Chilean maternity hospitals were filled with patients suffering from the effects of illegal abortions, and 39 per cent of maternal deaths were due to the same cause. The abortion rate for Latin America as a whole is estimated to amount to between 25 and 30 per cent of all live births. The Chilean Government has perhaps been the most sensitive to suffering inflicted by official policies, and last year the Minister of Health announced a family planning campaign-a courageous step for a Christian-democrat administration. The minister referred to the abortion statistics to justify this change of policy and said that family planning advice would be made available to married couples, particularly those in the lower-income groups, with the hope of reducing the number of abortions.

The Chilean lead has been followed by a number of other Latin American governments; family planning units, either allowed or sponsored by the governments concerned, are operating or about to operate in the Argentine, Bolivia, Brazil, Colombia, Dominica and Ecuador. The effects of the Pope's encyclical are most to be feared at the governmental level. For the individual, it is plain that the Church's doctrines on birth control are widely ignored. Abortion is a graver Roman Catholic sin than contraception. Governments, however, may feel stronger pressure from the Roman Catholic hierarchy to abandon the family planning campaigns they have begun.

Another spectre raised by the Pope's encyclical is that the World Health Organization may be denied its eminently proper and necessary interest in birth control. Proposals that the WHO should advocate birth control have several times been frustrated by its delegates from Catholic countries and only recently have they withdrawn their opposition. It is conceivable that these delegates may be re-instructed.

\section{Biggest Broker Yet}

As part of the deal by which Rolls-Royce obtained the contract to supply engines for the Lockhced 1011 airbus, Air Holdings, a British holding company, became one of the world's largest brokers of aireraft. Rolls-Royce, to overcome Congressional fears about the adverse effects on the American balance of payments of buying British engines for American aircraft, had to lay on a substantial export order for the 1011 . Through the offices of Lord Poole and his friends in the city and in Air Holdings, that company placed a firm order for thirty of the airbuses with an option on twenty more. This by all accounts is an entirely private speculation. On the face of things at least Air Holdings is planning to finance the operation from its own resources. It has bought the aircraft at a launching price, somewhere between $\$ 15$ million and $\$ 20$ million apiece, and hopes that by 1973, when it takes delivery of the first of its aircraft, the going price will be higher and the market unsaturated. 